\title{
Conditions of the Professionalization of the Surveying Graduate Profile in Poland
}

\section{List of Acronyms:}

AGH-WGGiIS - AGH University of Science and Technology in Krakow, Faculty of Mining Surveying and Environmental Engineering, hereinafter AGH.

UWM-GGCE - University of Warmia and Mazury in Olsztyn, Faculty of Geodesy, Geospatial and Civil Engineering (until 31 December 2014, Faculty of Geodesy and Land Management WGiGP), hereinafter UWM.

PW-WGiK - Warsaw University of Technology, Faculty of Geodesy and Cartography, hereinafter PW.

WAT-WILiG - Military University of Technology, Faculty of Civil Engineering and Geodesy, hereinafter WAT.

UWM, AGH, PW, WAT - reference to a source, results of surveys among graduates of respective universities.

\section{Introduction}

The economic development of Poland has affected expectations and requirements imposed on higher education institutions, including universities and faculties with a geodetic profile of studies. This observation suggests assessing the issue of adjusting the curricula to the needs of the economy and the current possibilities and methods concerning the transfer of knowledge, which are the subject of this study.

The need to professionalise the process of education is related to a series of endogenous and exogenous circumstances that have emerged as the consequence of changes in higher education in regard to the teaching process.

* University of Warmia and Mazury in Olsztyn, Faculty of Geodesy, Geospatial and Civil Engineering, Department of Land Management and Regional Development, Olsztyn, Poland 


\section{Aims of the Paper and Methods of Achieving Them}

Three research aims directly related to the subject matter undertaken have been set in the paper.

They have been formulated in the following manner:

- presenting the operating strategy of faculties with a geodetic profile of education;

- indicating evolutionary changes in the curricula as a result of economic transformations, the increasing possibilities of higher education institutions, changing expectations of students and emerging barriers in the labour market;

- presenting methods for adapting university structures to changing political and economic conditions.

The research hypothesis of this paper concerns the conviction that it is possible to optimise geodetic education in view of the changing political and economic conditions in a country using exogenous and endogenous possibilities available to the higher education system in Poland.

The research was conducted in two directions and the description of the research reflects the arrangement of this paper. First of all, the paper presents a case study of the strategy of a selected faculty. Second, it presents the results of a survey. The paper uses an educational strategy developed at the Faculty of Geodesy and Land Management at the University of Warmia and Mazury in Olsztyn, Poland. In this part is the case study. This specific faculty was chosen due to the intensive strategic transformations that have been implemented there in recent years. The second reason for choosing this faculty was the university's strong and proven contribution to the development of the Warmia and Mazury region as well as the scientific potential of Poland [16]. The study also draws on the main provisions of the strategy of the faculty's development, co-authored by the authors of this paper.

In addition, the theoretical consideration supported by literature on the subject has been supported by an analysis of statistical data derived from a survey concerning the professional path of graduates. The paper analyses the results of surveys conducted at four public Polish universities offering geodesy and cartography courses: AGH, UWM, PW, WAT.

These particular faculties have the longest academic tradition in this field in Poland. The paper presents qualitatively and quantitatively uniform results. Thus, the material may be used for comparative purposes. The purpose of tracking the professional careers of graduates in Poland [23] is to determine the impact of the knowledge and skills gained during a course of study at university on the professional paths of graduates. The studies should be used to modify the educational content in order to better suit the labour market's needs and to verify the relevance of the content delivered to students during their time at university. 
The methodology of tracking the professional paths of graduates in Poland is based on the following assumptions:

- the survey is permanent - it includes graduates of all years for first-level (bachelor's degree) and second level (master's degree), full-time and part-time courses;

- the survey is cyclical - follows up after graduation (up to six months), and three and five years, respectively, after graduation; thus, universities get feedback from graduates about the study process, skills gained and their satisfaction with the university courses they completed; also, the respondents declare when and where they entered the labour market, whether or not they have found employment and their professional situation each time they are surveyed;

- the survey is supposed to be exhaustive (full), but in reality, this is impossible, as some students do not sign consent for the processing of their personal data for the purposes of the study or do not agree to take part in the survey at all; another reason why the survey is not fully effective is that some graduates do not fill in the questionnaire;

- the most commonly used method is the CAWI quantitative survey, in which a personalised link to the questionnaire is sent by electronic mail to the e-mail addresses listed on questionnaires sent back during the previous stages of the survey;

- the panel method is used to survey graduates from the respective years, which makes it possible to determine the dynamics of the changes in the professional paths of graduates;

- the survey is confidential (anonymous questionnaire) and the data received are used only for statistical purposes;

- the universities calculate the questionnaire return rate, i.e., the number of questionnaires filled in by graduates; if a graduate does not respond to the questionnaire, a reminder is sent to him or her (usually one week after inviting graduates to participate in the survey); those who still fail to respond to the questionnaire are often e-mailed again or contacted by telephone, if possible.

Graduates may also use the online questionnaire to offer additional information, for example, their academic and professional activity as students or suggest post-graduate courses in fields that interest them.

The paper presents the results of the tracking of the professional paths of graduates in the period between 1 February 2013 and 31 January 2014. The analysis covers three survey cycles (the first cycle comes after the completion of the seventh term of a first-level university course in the academic year 2012/2013 $-1^{\text {st }} / 2^{\text {nd }}$ quarters of 2013; the second cycle comes after completion of a second-level university course in the summer term of 2012/2013 $-2^{\text {nd }} / 3^{\text {rd }}$ quarters of 2013; the third cycle starts after the completion of the seventh term of a first-level university course in the academic 
year 2013/2014 - $1^{\text {st }} / 2^{\text {nd }}$ quarters of 2014). The results, according to the methodology described above, concern the cyclical survey conducted within six months after graduation. In line with Polish legal regulations, the survey was addressed to all graduates of first and second-level university courses with a relevant graduation date. The potential sample of graduates at the four universities was over 2,000 in total. All of them received the questionnaire by electronic mail. The questionnaire return rate was relatively low: between $20-40 \%$, depending on the university. The effective sample size was between 422 and 793 questionnaires.

\section{Theoretical and Practical Aspects of the Professionalization of Education}

\subsection{Current Challenges and Possibilities to Improve the Educational Process}

According to observations by Vandell [27], the role of researchers and universities will gradually undergo a transformation; universities will become providers of education and knowledge programmes, while students will develop their own methods of knowledge acquisition. There is a much potential in developing the internet network, which would enable universities to extend the range of services offered by them and help students acquire knowledge.

On the one hand, students have access to modern information sources, not only traditional books and magazines but, more importantly, a growing number of sources of information that are online (network) or electronic (data carriers). On the other hand, the informatisation of education creates new possibilities for delivering knowledge and added flexibility in the educational process [19]. It becomes possible to offer students online courses on open platforms, training materials are easy to share, services may be accessed even by non-members of a given scientific institution, and it is possible to create virtual units (e.g., dean's offices) or virtual classes of students from across the world [1]. The very fact that the teacher and students are connected via the internet during a lesson and may use multimedia equipment creates numerous possibilities to prepare classes using text, sound, picture or video programmes and other applications as well as to modify lessons on an ongoing basis, make changes, manage data, etc. [22]. Moreover, according to Wegner et al. [28], informatisation of the educational process may help emphasise the paradigms of the "student as worker" and the "teacher as coach". The role of the teacher is to prepare the work environment, predict student needs and ensure proper conditions for the education process. The changes are not only local but also global - these matters are not limited to the education system in Poland and can be applied in any country. Particular attention should be paid to issues concerning expansion of the programme scope of higher education institutions, broadening the educational offer and the increased risk of a system-based process of education. The discussed group 
of factors of the endogenous characters should also include changes in the attitudes of students and teachers. Changes in students' attitudes have evolved towards reduced involvement in their own work, replaced by procedural work carried out mainly through (usually passive) participation in lectures and practical classes.

\subsection{The Higher Education System in Poland - Implications of the Economic and Political Changes}

The political changes which took place in Poland in 1989 started not only a gradual process of the market approach towards education, but also introduced market principles to the academic labour market $[4,6]$.

When attempting to analyse these issues, the following fundamental questions must first be asked:

- How the higher education system in Poland has changed during the transition?

- How universities have had to respond to it?

- Specifically how has the teaching of geodesy/surveying had to change and how has Polish universities in particular responded?

Until 1989, Poland was a socialist country, and one of the aftermaths of this political system was a specific higher education system. In most cases, graduates were not prepared to enter the labour market on their own. Consequently, at the onset of the political transformation, Polish society had knowledge that was adequate to the old, non-competitive economic system [3]. Such an education system required reforms and the need to adapt both the quality and form of education to the changing economic reality and labour market. The most crucial problems of the Polish education system in the early 1990s were the monopolisation of the higher education system (as well as the entire domain of education), insufficient financing and investment, and a lack of primary and secondary education (low level of specialisation, not enough teachers, unreliable historical and social information, imprecise curricula) [26]. The most important challenge facing the higher education system before 1989 was to adapt it to market conditions by reducing the number of jobs and demonopolising and decentralising the system [20].

It is believed that the process of transforming the higher education system at the time of the political transformation of the early 1990s was only partially successful. The number of students increased unexpectedly, which resulted in a growing number of universities. Naturally, this resulted in the development of a private higher education sector. Consequently, the academic infrastructure (buildings, curricula) started spreading and dispersing at a fast rate. The rapidly growing possibilities of the higher education system (the number of students multiplied by several times) were not accompanied by a growth in the number of staff who could teach these students. How was the problem solved? First of all, a teacher could work in a number of universities, often in distant locations. Second, the requirements for students 
were lessened. Third, "book teaching" became the dominant trend and the elements of practical teaching were reduced or even eliminated as there was simply no time for that. Fourth, young teachers were left on their own to improve their professional qualifications - more senior teachers had no time to teach the profession to their younger colleagues. Finally, the simple rules of the market economy resulted in an increase in the social and economic freedom of teachers.

Today academic teachers in Poland, motivated by opportunities created by the market economy, started to become involved in various business activities, sometimes at the cost of the performance level of their academic duties. This led to structural changes in the attitudes of academic staff.

\subsection{Factors Influencing Modernisation of the Geodetic Education System}

If the description above was education in Poland prior to the 1990s, the beginning of the $21^{\text {st }}$ century was a period of awakening. The problems listed above were quickly noted and relevant preventive measures undertaken. Polish universities started limiting the possibilities of working in several institutions at the same time, introduced education accreditation processes, returned to promoting professional development and self-development of academic teachers, and undertook the process of increasing requirements for students and improving evaluation systems of learning outcomes. Universities quickly responded to the imperfections that developed, in a natural manner, as a result of the political transformation. However, implementing them was, and still is very problematic. The main problem is the loss of relationship "a very good teacher means a good student" - which is natural for universities. An undereducated teacher without professional experience and engaged in many affairs not connected with teaching is a poor role model. The teaching of surveyors at Polish universities was subject to the same processes as higher education in general and described in the previous chapter. However, there is one major difference, teaching geodesy required and still requires good teaching infrastructure (measuring equipment, specialist computer programs). Thus, the number of faculties teaching future surveyors did not explode. It should be noted that certain conservatism has always existed in geodesy circles, which also helped implement the transformation process.

The process of professionalization with regard to the education of geodesists in Poland is also conditioned by various exogenous elements. The most important of them include:

- Combining studies and professional work - which leads to a reduction of in the students' own involvement, as they devote a part of their attention to professional work - the reaction of Polish universities offering geodesy courses was the development of remote teaching methods, the development of remote library access systems and the introduction of project work outside the classroom. 
- Barriers in the labour market, related e.g. to structural unemployment which leads to discouraging "deepened" studies, or putting more effort into one's own work - Polish universities tried to solve the problem by switching from strictly vocational education (surveyor and only surveyor) to teaching broader subjects so that graduates could have more flexibility and choices in their professional path and the opportunity to find employment in many other areas that could be broadly defined as geomatics (compare this to the Czech example) [10].

- Structural changes concerning education at lower levels - lowering requirements in primary and secondary schools contributes to worse preparation of candidates for higher studies - in this respect, so-called remedial classes (e.g., mathematics and physics geodesy courses), supplementary courses (e.g., in information technology) and dedicated training (namely to develop soft skills) were introduced.

- Intense competition between state universities and private high schools, which leads to "negative competition in the level of education" - this phenomenon was successfully limited on the legislative level by increasing the requirements for geodesy and cartography teaching staff, especially in the case of second-level courses.

- Frequent changes in legislation governing higher education - which leads to introducing changes in the curricula that have not been subject to practical evaluation.

The main impression is that the legal framework in Poland is very rigid and has not responded to market forces. This makes it difficult to put on new curriculum that reflect the changing demands by students and employers. It also obliges students to spend set amounts of time on particular subjects, which limits the ability to develop transferable skills and ones that are in demand in the market place.

In 2011, major legislative changes were introduced to the education system as a result of the adoption of the Polish Higher Education Act [23], the implementation of the so-called Bologna Process, and the end of outdated "teaching standards", no longer relevant to the existing needs. Currently, it is easier to change curriculum, as it is no longer limited by legal restrictions. The types of changes depend on the labour market needs and the demand for specific types of graduates communicated by employers, that is, the demands of the free market.

In the literature, there are many accounts of the education system in general and geodesy teaching in light of the political changes in European countries [2, 5, $7,9,11,21]$. The measures undertaken in Poland in 2011 differentiate the country from others, such as Russia or Serbia, where restrictive systems based on imposed standards are still dominant.

An important factor in favour of professionalization of the process of education is the observation that today's geodetic education also includes many related 
specialisations, e.g. spatial management, property management, valuation and appraisal [13]. The need to professionalise education is unquestionable, and these issues are broadly discussed in the international literature [24, 18, 14].

The literature provides many reports in this field. Grzesik et al. [15] indicate the need to take action towards the development of professionals capable of meeting growing expectations in a modern, dynamic perspective. A dynamic approach means, on the one hand, using the professional experience of practitioners in education, e.g., the experience of real estate appraisers who naturally contribute their up-to-date professional experience gained in the real estate market to academic teaching.

On the other hand, the dynamics is reflected in the growing qualifications of graduates hired by employers. For this purpose, Polish universities establish and maintain special committees tasked with constantly improving the curricula. Several publications $[30,29,17]$ have discussed the problem of dialogue between "academics" and "practitioners" in the field of property appraisal and other disciplines. In their opinion, the teaching curricula in the field of geodesy and property appraisal should competently prepare graduates for work in state and local government units; design offices, enterprises related to land management, including those operating in the field of appraisal, development agencies, consulting companies, business environment companies, in their own companies dealing with property appraisal, research institutions and research and development centres [8]. To meet these needs, Polish universities teaching surveyors, among others, develop an educational offer after discussions with employers, invite specialists in respective areas of knowledge to teach students, organise seminars and open lectures, add internship programmes to curricula and organise competitions, where students can win on-the-job training in geodesy companies.

From this perspective, professionalization goes hand-in-hand with specialisation, the need to adjust technological resources or to introduce new forms of learning and supplementary training, e.g. classroom learning, online learning, mobile learning and blended learning, which will combine traditional classroom learning with online and mobile learning in order to maximise the understanding of theoretical principles, gaining knowledge and development of technical, practical and professional skills [12].

There are two issues here. One is what students need to know and the skills they need to develop. The other is how they can acquire them.

Polish universities solve the first problem by a system of permanent evaluation of learning outcomes of the academic teacher, the student, the graduate and the employer. Each evaluates learning outcomes in a specific context. The process is based on the evaluation conducted during a university course and at six months, three years and five years, respectively, after graduation. The second problem is solved in the way described above. Adding elements delivered by practitioners to teaching processes is a must. 


\subsection{Shaping a New Profile of a Geodesy Course Graduate - Case Studies}

\section{Education Strategy at the UWM}

The Faculty of Geodesy, Geospatial and Civil Engineering (GGCE) at the University of Warmia and Mazury in Olsztyn (in the north-eastern part of Poland) seeks to establish its permanent position on the regional, national, European and global academic levels while providing education at the university level. It also aims at increasing competitiveness and creating an image as a modern, student - and employee-friendly faculty. The strategy for educating geodesists in the faculty is based on its mission [25, p. 5]:

The mission of the Faculty is to educate specialists in the field of geodesy, cartography and land management, in cooperation with administration, professional communities and other stakeholders of the education process. The broad scope of university education will make it possible for graduates to gather knowledge and skills opening career opportunities in many disciplines and facilitating adjustment to market requirements in any time perspective.

To maintain its competitiveness, while taking into account the significant increase in the expectations of students, employers and other entities, the Faculty must consequently implement this mission. It must become a creative entity as regards to academic as well as research and development potential, methods and effects of the process of education. Acting in accordance with the mission, the Faculty will also be able to improve its recognisability and attractiveness in the international arena. By cultivating a tradition of academic excellence, and therefore requirements towards students and $\mathrm{PhD}$ students, the Faculty will strive towards providing them with appropriate studying conditions. The Faculty can achieve this by introducing modern teaching programmes and didactic methods adjusted to the needs of the contemporary labour market and providing foundations for individual development. The competitiveness of the Faculty will be based on maintaining the best university tradition, with a modern approach to market challenges, demonstrated by significant flexibility and a quick response to individualized needs of contemporary customers, originality of teaching programmes and methods and a strong administrative culture encouraging the achievement of strategic aims.

The priorities concerning the education of geodesists in GGCE [25, p. 14]:

- We want to educate students at a level that permits them, after completing studies, to freely develop their professional position.

- We want to improve teaching processes carried out at the Faculty through: improving the didactics, combining education with requirements defined by employers and the professional community.

- We want to create an image as a modern, student- and employee-friendly Faculty, through improvement of quality assurance procedures concerning teaching, information processes and the organisation of all-faculty seminars and conferences.

The strategic aims in the field of education have been defined as follows:

- Internationalization of studies through opening of the Faculty to broad international exchange. At the faculty, two international curricula were 
developed: Geoinformatics and Modern Real Estate Management, and the university started promoting these courses in Europe and Asia; the process of scientific and academic staff exchange was intensified using programmes offered by institutions in Europe, North and South America and Asia; the student exchange was significantly expanded within the framework of such international exchange programmes as ERASMUS+; all the procedures of the European Credit Transfer System (ECTS) were implemented.

- Modernization of the educational offer in the specialty of geoinformatics. Based on experience gained in the process of discussing curricula with employers, professional organisations, national and local government administration and feedback from internal stakeholders in the geodetic education process (students, graduates and employers), education in the specialty of geoinformatics was modified and adjusted to the needs of the labour market and information economy.

- Constant improvement of the teaching level according to social, economic and cultural needs of the region and the country. Identifying and describing the issues that affect the quality of education made it possible to undertake a number of measures to improve the education level. The most important were the following: teachers were limited to working in two jobs only and simultaneously teaching a second-level course outside GGCE was prohibited; a rating system was introduced to evaluate the work of academic teachers; students were allowed to write diploma theses about topics and issues suggested by employers, competition procedures were implemented, and employers could reward the best students with prizes, on-the-job training, or employment contracts.

- Development and introduction of procedures related to the faculty quality assurance system in the field of education, research and administration. The faculty implemented an Internal Educational Quality Assurance System. The basic objectives of the system are:

- constant improvement of the quality of education,

- ensuring coherence between the assumed goals and learning outcomes,

- transparency of educational quality assurance procedures,

- making the educational offer more attractive and more competitive,

- adjusting the education to the needs of the Polish and EU labour markets,

- ensuring a link between education and scientific research conducted at the faculty,

- making the best use of financial resources,

- improving the conditions of classes,

- individual development of students,

- creating a system of communication with potential students and enhancing communication with the faculty's current students and graduates. 
Each of the elements of the quality assurance system listed above went through an implemenion procedure that tasked the units responsible for implementation as well as performance, review and evaluation of the respective elements, removal of any irregularities and with making improvements. As a result of the measures taken, the faculty's educational processes were tailored to the needs of the local and regional labour markets. The faculty's graduates will have more chances in the labour market, not only in geodesy and cartography but also in geomatics.

\subsection{Adjustment of the Curricula at Choosen Polish Universities}

This chapter presents selected results of the tracking of the professional paths of graduates. The purpose of the analysis was to confirm the research goals defined in the paper.

Table 1 presents the results of surveys among UWM, AGH, PW and WAT graduates in terms of employment and its various forms. An analysis of Table 1 leads to the conclusion that more than $70 \%$ of AGH, PW and WAT graduates found work in various forms of employment. For UWM graduates, the ratio was $45 \%$. Continued education was reported by about $5 \%$ of AGH graduates, $21 \%$ of WAT graduates and $37 \%$ of UWM graduates. Self-employment was declared by $4-7 \%$ of respondents. The lowest unemployment rate was declared by UWM graduates (10\%), followed by $11.0 \%$ of AGH graduates, $16.3 \%$ of WAT graduates and $22.4 \%$ of PW graduates.

The results should be analysed in the context of the research methodology. The respondents' answers were based on their previous professional experience no earlier than six months prior. An exception to this were those who worked as students.

Table 1. Professional status of graduates of inspected universities [\%]

\begin{tabular}{||l|c|c|c|c||}
\hline \multicolumn{1}{|c|}{ Professional status of the graduate } & AGH & UWM & WAT & PW \\
\hline \hline I am employed & 78.8 & - & $83.7^{*}$ & - \\
\hline I have a guaranteed employment & 1.5 & - & - & - \\
\hline I am working to the contract of employment & - & 32.0 & $74.4^{* * *}$ & 43.8 \\
\hline I am working based on the civil law agreement & - & 13.0 & $12.8^{* * *}$ & 22.4 \\
\hline Other employment & - & - & $2.6^{* * *}$ & 4.8 \\
\hline Different employment statuses & 73.7 & 45.0 & $89.8^{* * * *}$ & 71.0 \\
\hline I am leading business activity & 3.6 & 4.0 & $10.2^{* * *}$ & 6.6 \\
\hline I am continuing the education, I am not job-hunting & 5.1 & - & - & - \\
\hline I am continuing the education & - & 37.0 & $20.9^{* *}$ & - \\
\hline I am job-hunting & 9.5 & - & - & - \\
\hline I am not working, I am not job-hunting & 1.5 & - & - & 22.4 \\
\hline I am unemployed & - & 10.0 & $16.3^{*}$ & - \\
\hline Total & 100.0 & 100.0 & - & 100.0 \\
\hline
\end{tabular}

* in the questionnaire form of WAT lines of text 1 i 11 are summing up to $100 \%$.

** in the qiuestionnaire of WAT - line of text 8 - is regarding persons carrying the learning on. $79.1 \%$ graduates chose an option "I am not contnuing education".

*** in questionnaire of WAT - lines of text $3-5$ i 6 are summing up to $100 \%$.

**** approximate data in relations to the attention. 
Table 2 shows how long it took graduates of three universities to find employment. According to Table 2, more than $70 \%$ of AGH graduates, about $93 \%$ of PW graduates and $97 \%$ of WAT graduates found work within six months after receiving their university degrees.

Table 2. The time of a job-hunt of graduates [\%]

\begin{tabular}{||l|c|c|c||}
\hline \multicolumn{1}{|c|}{ Time of finding employment } & AGH & WAT & PW \\
\hline \hline I didn't seek the employment & 19.1 & 0 & - \\
\hline Below 1 month & 39.1 & - & 51.4 \\
\hline I worked already in the course of studies & - & 47.2 & - \\
\hline Less than 2 months & - & 19.4 & - \\
\hline 1-3 months & 20.9 & - & 30.9 \\
\hline 4-6 months & 10.9 & - & 11.6 \\
\hline 2-6 months & - & 30.6 & - \\
\hline Above 6 months & 7.3 & - & 6.1 \\
\hline 6-12 months & - & 2.8 & - \\
\hline No data & 2.7 & - & - \\
\hline Total & 100.0 & 100.0 & 100.0 \\
\hline
\end{tabular}

Source: UWM, AGH, WAT

Table 3 shows the results of a questionnaire concerning the correlation between students' education and their jobs. According to Table 3 more than $85 \%$ of AGH graduates found work wholly (or partly) in line with their education. In the case of UWM graduates, the rate was above $50 \%$ and for WAT graduates, more than $33 \%$.

Table 3. The compliance of the job with educating graduates $\%$

\begin{tabular}{||l|c|c|c||}
\hline \multicolumn{1}{|c|}{ Compliance of the job with the education } & AGH & UWM & WAT-WILiG \\
\hline The job in accordance with the education & 70.9 & - & 33.3 \\
\hline The job closely connected with the speciality of education & - & 6.2 & - \\
\hline The job closely connected with the direction of study & - & 33.3 & - \\
\hline The job partly in accordance with the education & 16.4 & - & - \\
\hline The job partly connected with the direction of study & - & 11.1 & - \\
\hline The job partly or fully in accordance with the education & 87.3 & 50.6 & 33.3 \\
\hline The job incompatible with the education & 7.3 & - & 66.7 \\
\hline The job unrelated to the direction of study & - & 9.9 & - \\
\hline No data & 5.5 & 39.5 & - \\
\hline Total & 100.0 & 100.0 & 100.0 \\
\hline
\end{tabular}


Figure 1 presents the results of the survey conducted among graduates concerning the application of knowledge, skills and competence acquired during their studies. The survey was conducted among all graduates (employed and unemployed). In the opinion of $50 \%$ of graduates, they use knowledge, skills and competence acquired during their studies at a moderate, high or very high level. 10\% of graduates use those elements at a low or very low level. A surprising number of students $(39.5 \%)$ did not want to share any knowledge in this regard. The reason for the high rate of non-response might be the fact that $37 \%$ of graduates of first-level courses at UWM continue their education (see row 8 in column "UWM" in Table 1) and another $10 \%$ are unemployed. This last element should be a significant finding to be addressed by the universities, which should intensify work to improve systems providing information about learning outcomes.
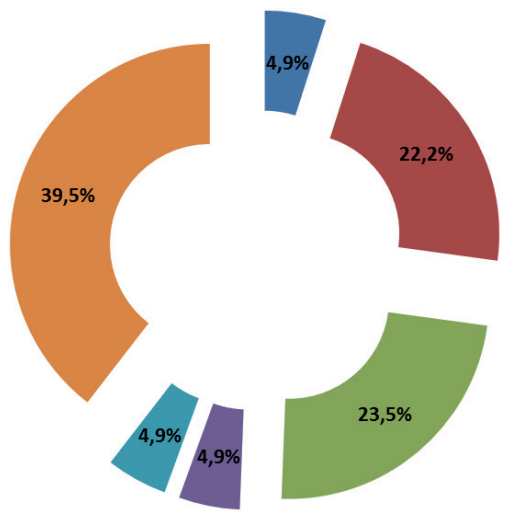

wery high

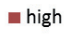

moderate

small

very small

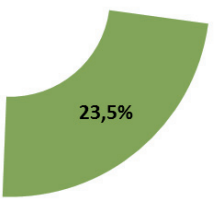

no data

Fig. 1. Extent to which knowledge, skills and competence acquired during studies are used in work

Source: UWM

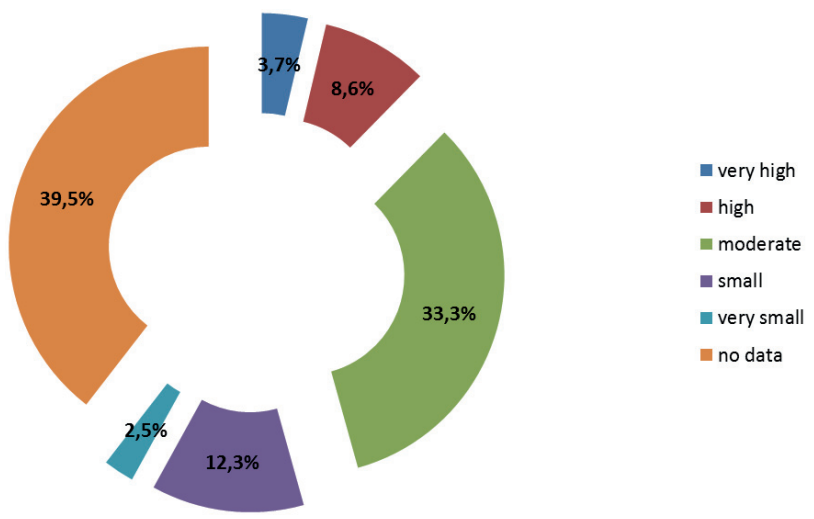

Fig. 2. Degree of usefulness of education in the context of labour market requirement Source: UWM 
Figure 2 presents the results of a survey conducted among graduates concerning the degree to which their education corresponds to current requirements of the labour market. In the opinion of about $45 \%$ graduates, their education meets the current requirements of the labour market at a moderate, high or very high level. $15 \%$ of graduates assess those elements at a low or very low level.
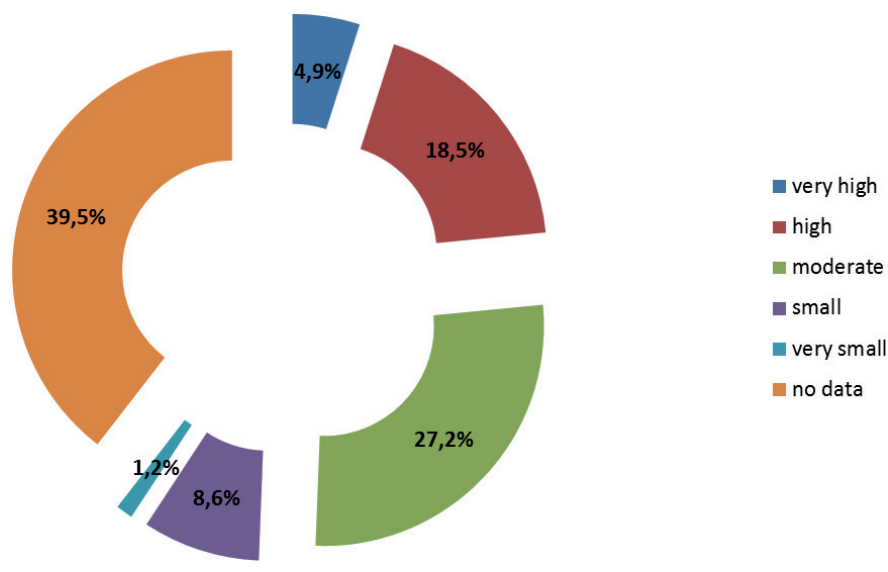

small

very small

no data

Fig. 3. Degree to which a graduate is prepared for self-education and creative problem-solving in professional work

Source: UWM

Figure 3 presents the results of a survey among graduates concerning the degree to which the studies prepared the graduate for self-education and creative problem-solving in professional work. In the opinion of $50 \%$ of graduates, their studies prepared them for self-education and creative problem-solving at work at a moderate, high or very high level. $10 \%$ of graduates assess these elements at a low or very low level.

Figure 4 presents the results of a survey among geodesy and cartography graduates of the Faculty of Mining Surveying and Environmental Engineering at AGH in Cracow concerning the level of practical application of the knowledge and skills gained as students. Some $45 \%$ of graduates declared they use qualifications gained as students at a high or very high level. About $44 \%$ of graduates used these elements at a moderate level, and 7\% did not use the knowledge and qualifications gained as students at all.

Figure 5 shows the results of a survey among graduates of the Faculty of Geodesy and Cartography at PW in Warsaw concerning the use in their work of the knowledge they gained at university. About $35 \%$ of graduates declared they use knowledge gained as students at a high or very high level, 37\% at an average level, $20 \%$ at a low level, and $10 \%$ at a very low level. 


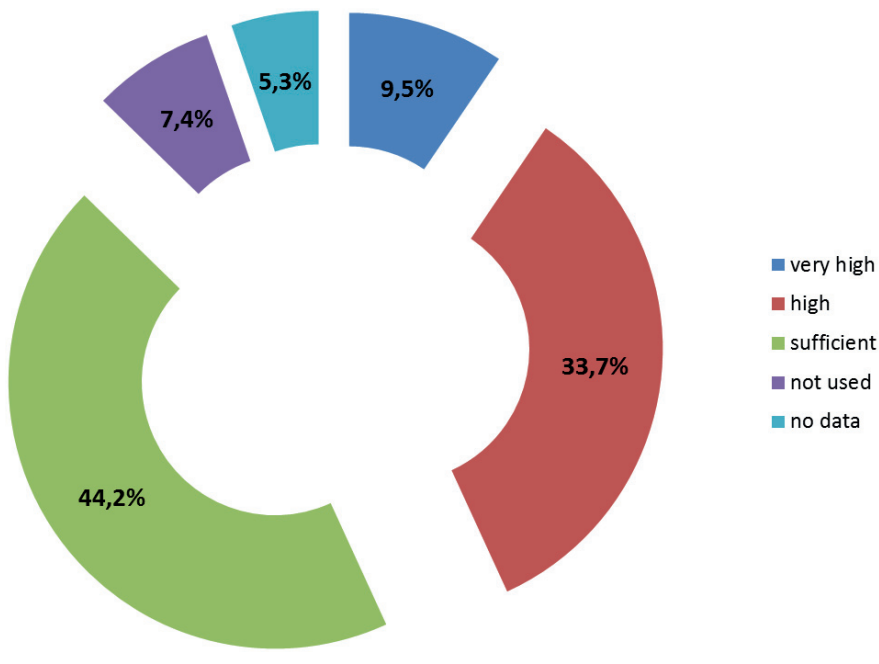

Fig. 4. The level of application of the knowledge and skills acguired during studies Source: AGH

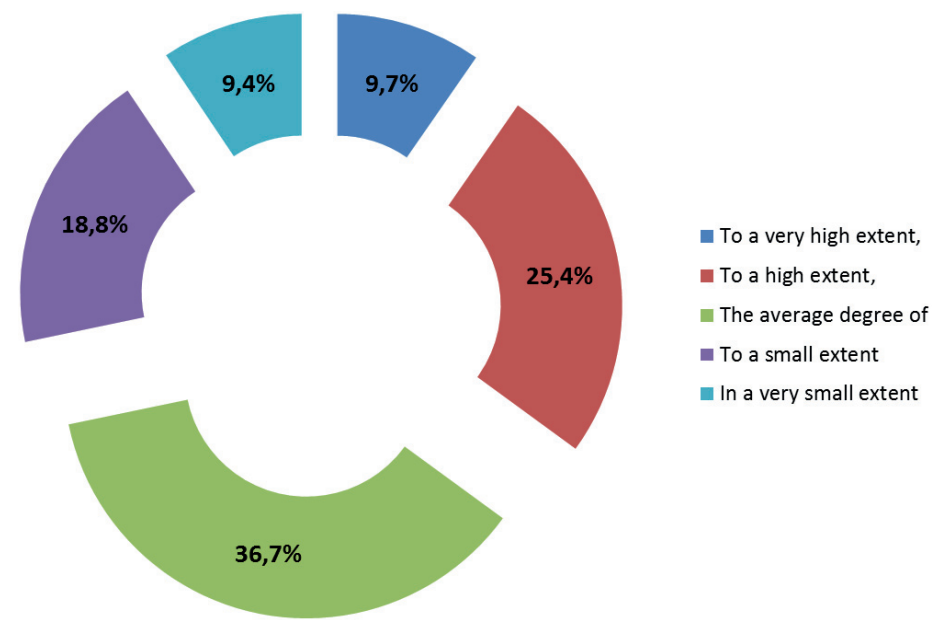

Fig. 5. Using the knowledge gained at university at work Source: PW

Some $62.9 \%$ of graduates of the Faculty of Civil Engineering and Geodesy in Warsaw answered positively to the question whether the knowledge, skills and competencies gained as students helped them find employment. Of these graduates, $58.3 \%$ answered positively to the question whether, according to them, the curriculum and study materials were useful in their work. Some $22.9 \%$ answered "yes" to the question whether the university course at WAT taught them a foreign language at the level required in their work. 


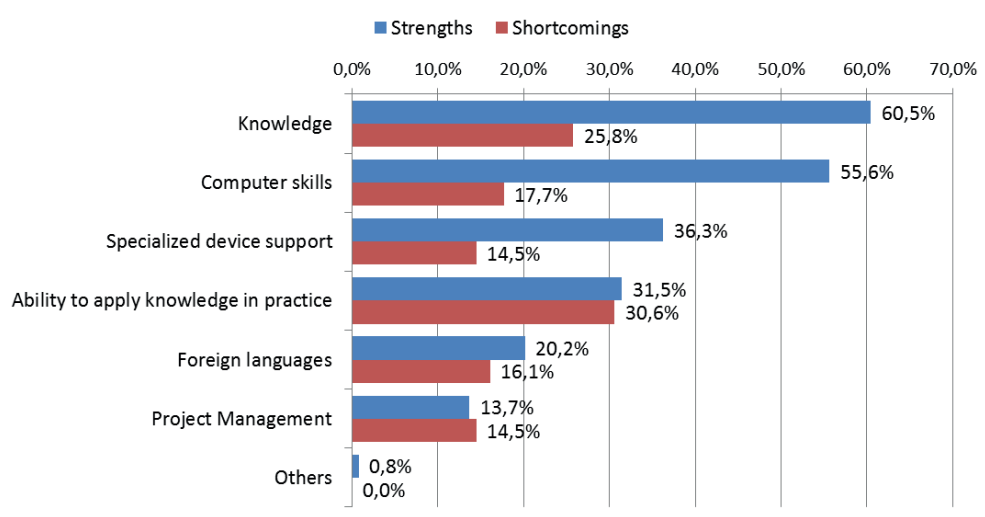

Fig. 6. Evaluation of studies in the context of preparing graduates to the performed work in the area of adventages and gaps - knowledge and skills, in \%

Source: AGH

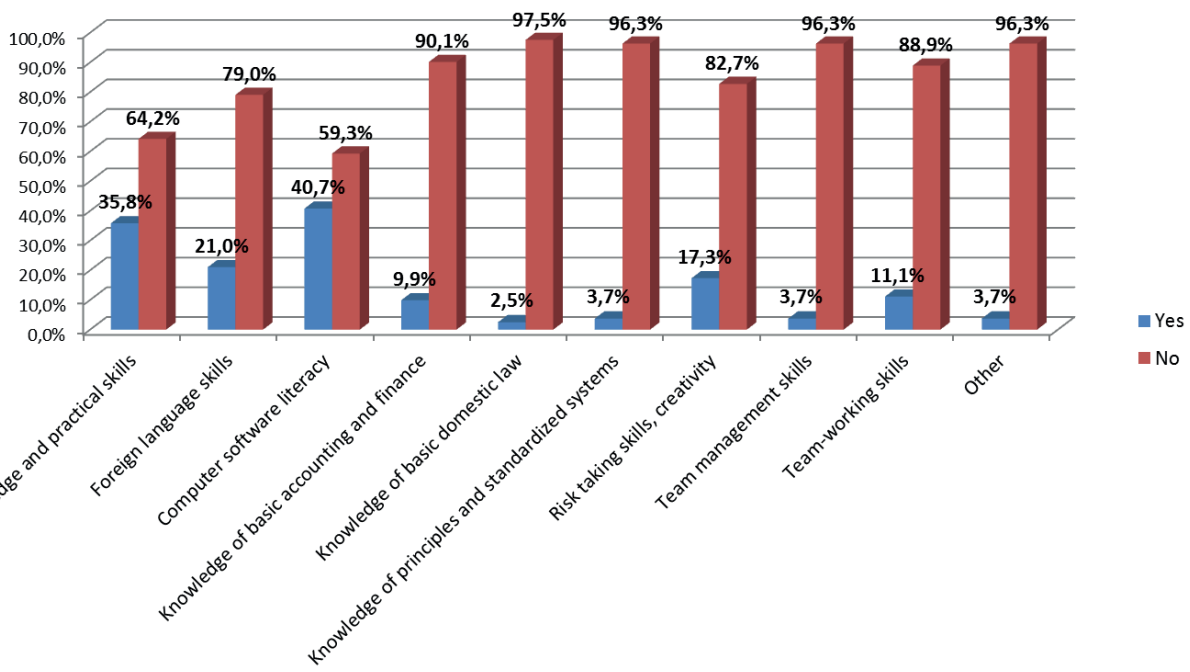

Fig. 7. Educational areas requiring extension/deepening to provide graduates with greater chances in the labour market

Source: UWM

Figure 6 shows the results of a survey among graduates of the Faculty of Mining Surveying and Environmental Engineering at AGH in Cracow concerning their evaluation of a university course in terms of preparing them to work in their professions: strengths and weaknesses with respect to knowledge and skills. About $60 \%$ of graduates declared that a university course prepared them to work in their professions in terms of computer knowledge and skills, while $35 \%$ said it did in terms of operating specialist equipment and the ability to apply knowledge in practice, and 
$20 \%$ reported it helped in terms of foreign language skills, and $14 \%$, in terms of project management. The most deficiencies (about 30\%) were reported in the area of practical application of knowledge, followed by a lack of knowledge (25\%), insufficient computer skills (18\%), weak foreign language skills (16\%) and lack of project management experience (15\%).

Figure 7 presents the results of a survey among graduates concerning the area of education which should be extended/deepened in order to provide graduates with better chances in the labour market. About $41 \%$ of graduates are of the opinion that the area that requires extension/deepening is the area concerning the operation of computer software/IT systems, $21 \%$ - the area of foreign languages, $17 \%$ - the area of risk-taking, creativity and entrepreneurship skills, about 10\% - the area concerning the basics of accounting, finance and team management skills.

The results of the survey concerning the professional path of graduates are confirmed by the results of own analyses carried out by the administrations of the Faculty of Geodesy, Geospatial and Civil Engineering in Olsztyn, showing that adjustment of the curricula in Poland should lead to taking, among others, the following actions:

1. concerning educational areas that should be extended/deepened to provide the graduate with greater chances in the labour market - the measure stems from the surveys discussed in chapters 3.2 and 4.1;

2. aiming at increasing the degree of adequacy of education in relation to labour market requirements - the measure stems from the surveys discussed above as well as other surveys conducted among employers (not discussed here);

3. increasing practical preparation of graduates entering the labour market the measure stems from the observations of persons responsible at the university for reviewing vocational training and the conclusions of joint meetings of academics and businesspeople;

4. facilitating taking up work beyond the geodetic sector, which will affect job-search effectiveness - the measure stems from the surveys discussed above, the results of analyses conducted by specialist agencies and associations, and our own observations associated with the need to extend the educational offering to the area of geomatics;

5. increasing the potential for innovation, and therefore preparing graduates to open their own businesses - this measure is necessitated by a very low rate of self-employment in business and a very limited interest in innovative geoinformation technologies, which are very expensive;

6. increasing the degree to which the graduate is prepared to undertake self-education and creative problem-solving in professional work - the measure stems from the surveys discussed above and from direct interviews with graduates and employers, who highlight the need to introduce elements of entrepreneurship, teamwork and individual work skills, project team management skills, etc.; 
7. applying professional work of knowledge, skills and competence acquired during studies - the measure stems from the surveys discussed in chapters 3.2 and 4.1 ;

8. enabling graduates to search for work not only in micro - and medium-sized companies, but also in large enterprises - the measure stems from surveys conducted among graduates, most of whom find employment in small companies; only a few percent of graduates find employment in medium-sized and large companies.

The critical analysis of the education processes in the Faculty of Geodesy, Geospatial and Civil Engineering in Olsztyn requires the following restructuring steps:

1. introduction to the curricula of increased professional training carried out at the employers' sites - a two-prong measure was taken: within the existing framework, the number of hours of vocational training requiring the direct participation of employers was increased, and a national programme for practical training of students from the sixth term of studies onwards was developed;

2. reduction of practical training provided by non-practitioners - relevant limitations were introduced in the internal educational quality assurance system;

3. closer relations between professional subjects and land surveying practices all new curricula and modifications to existing curricula require the positive opinion of employers in order to become effective;

4. carrying out practical works with the use of "real examples" occurring in land surveying operations - relevant limitations were introduced in the internal educational quality assurance system;

5. reducing the number of subjects by increasing the number of hours allocated for lectures and practical classes - this will provide for faster changes in the curriculum without the need to introduce changes in study syllabuses - relevant limitations were introduced in the internal educational quality assurance system;

6. introduction of modern specialist software to the curricula - curricula were amended and agreements were signed to provide all students with access to specialist software;

7. elimination of subjects carried out only in the form of lectures - relevant limitations were introduced in the internal educational quality assurance system;

8. introducing to the curricula content concerning: professional project management, entrepreneurship (establishing a business), administrative law, modern software development technologies, foreign language courses at the business level, risk assessment - the process of amending the curricula was initiated and is expected to be completed in 2016; 
9. introduction of teaching modules helping to acquire soft competences in the field of: self-education, creativity in action, creative problem-solving, team work, cooperation, making assessments, drawing conclusions, criticising bad solutions, etc assessment - the process of amending the curricula was initiated and is expected to be completed in 2016.

\section{Detailed and Overall Conclusions}

The rate of transformation occurring in social and economic life creates an impact on the character of changes in which higher education institutions participate. Taken comprehensively, the issues under discussion concerning conditions for professionalization of education, elements related to educational strategy in a faculty with a geodetic profile and the need to adjust the curricula, reflect the changes occurring in higher education and in social and economic transformations in Poland and in other European countries. This paper discusses many important current issues, which at the present level of research cannot be verified due to the strategic, long-term problems presented. Active participation of the university to emerging challenges and economic problems provides an indispensable element defining the presence of the educational process in domestic and global economic processes, providing for interests of all stakeholders: students, university employees and employers.

The most important conclusion of the paper is that universities should undertake measures towards the professionalization of education. It highlights the need to take, among others, the following actions:

- extending areas of education so that graduates have better chances in the labour market, also through the possibility of taking up jobs outside the geodetic sector;

- increasing the innovation potential and preparing graduates to establish their own businesses;

- increasing the degree of graduate preparation for self-education and for creative problem-solving in professional work.

According to the authors of the paper, the goals may be achieved by the implementation of restructuring measures. The most important of them are the following:

- increasing the professional training carried out at employers to the curricula;

- introducing modern specialist software to the curricula;

- expanding the curricula with content concerning: professional project management, entrepreneurship (establishing a business), administrative law, modern software development technologies, business foreign language courses, risk management,

- introducing teaching modules facilitating the acquisition of soft skills in the field of: self-education, creativity in action, creative problem-solving, team work, cooperation, making assessments, drawing conclusions, criticising bad solutions, etc. 
To conclude the presentation of the results of the analyses discussed in the paper, it should be stated that:

- Polish universities offering geodesy courses have coped well with the political transformation;

- evolutionary changes in curricula have been so successful that Polish universities educate geodesy and cartography graduates at the highest European level;

- the exemplary strategy of development discussed in the paper is open and dynamic, and it draws on the best European models;

- universities actively respond to the changing expectations of students, by adapting educational tools to the needs expressed by them;

- Polish universities try to overcome the barriers of the labour market by developing practical education beyond classical geodesy and cartography, e.g., geomatics;

- the current pro-development activities should soon result in the internationalisation of education and development of problem-solving-based education;

- as a result of intensive efforts to develop educational quality assurance systems, educational imperfections are removed from not only curricula but also individual teaching subjects.

In a reality with changing political and economic conditions, a major effort has been undertaken in Poland to optimise educational processes concerning geodesy university courses. These changes are evaluated positively. The education system at geodesy faculties is not fossilised. Poland can well adapt not only to exogenous but also to endogenous changes. An example of the former type of changes is the implementation of the Bologna Process, and of the latter, the system to track the professional paths of graduates. The tools available to the Polish higher education system are sufficient to flexibly shape the profile of a graduate to easily compete not only on the domestic labour market but also on the European one.

The methods discussed above of adapting university structures to the changing market, political and economic conditions, optimisation of curricula to match the requirements of the labour market and information economy, as well as the practical measures taken in order to make education parallel with future professional paths (not only in geodesy) lead to the conclusion that the hypothesis made in the paper is true.

\section{References}

[1] Alcorn R.L., Cane D.E., Chasen M.L., Chi T.R., Gilfus S.R., Perian S., Pittinsky M.L.: U.S. Patent No. 6,988,138. Washington, DC: U.S. Patent and Trademark Office, 2006, [on-line:] https://www.google.com/patents/US6988138 [access: 18 February 2015]. 
[2] Aleksic I., Mansberger R., Muggenhuber G., Navratil G., Ninkov T.: Academic Education and Continuous Professional Development in Surveying: A Review of the Situation in Austria and Serbia. [in:] International Scientific Conference and XXIV Meeting of Serbian Surveyors "Professional practice and education in geodesy and related fields”, Kladovo - „Djerdap“ upon Danube, Serbia, 2011, pp. 1-8.

[3] Auleytner J.: Edukacja bez granic. Wyższa Szkoła Pedagogiczna Towarzystwa Wiedzy Powszechnej, Warszawa 2001.

[4] Banach C.: Polska szkoła i system edukacji: przemiany i perspektywy. Wydawnictwo A. Marszałek, Toruń 1995.

[5] Boes U., Pavlova R.: The education challenge for the geodetic and spatial data infrastructure profession. [in:] The First Serbian Congress of Geodesy, Belgrade, December 1-3, 2011, pp. 1-6.

[6] Bogaj A., Kwiatkowski S.M., Szymański M.J.: System edukacji w Polsce: osiagnięcia, przemiany, dylematy. Instytut Badań Edukacyjnych, Warszawa 1995.

[7] Bolshakov V.: Higher Geodetic and Cartographic Education in Tsarist and Soviet Russia. Cartographica: The International Journal for Geographic Information and Geovisualization, vol. 7(2), 1970, pp. 116-125.

[8] Buśko M., Przewięźlikowska A.: Analysis of the Quality of Academic Education of Geodesy and Cartography Graduates with Respect to Employment in Geodesy Administration. Geomatics and Environmental Engineering, vol. 4, 2010, pp. 21-32.

[9] Cashin S.M., McGrath G.: Establishing a modern cadastral system within a transition country: Consequences for the Republic of Moldova. Land Use Policy, vol. 23 (4), 2006, pp. 629-642.

[10] Cerba O., Jedlicka K., Jezek J.. Geospatial data visualisation in geomatics curriculum. International Cartographic Conference, 2009, [on-line:] http://icaci.org/ files/documents/ICC_proceedings/ICC2009/html/nonref/18_11.pdf [access: 22 February 2015].

[11] Drobne S.A.M.O., Petrovic D., Lisec A.N.K.A.: New Study Programs of Geodetic Engineering in Slovenia. [in:] Proceedings of the International Congress on Geomatics Education in Europe, Warsaw, Poland 2007, pp. 1-13.

[12] El-Mowafy A., Kuhn M., Snow T.: Blended learning in higher education: Current and future challenges in surveying education. [in:] Teaching and learning in higher education: Western Australia's TL Forum, Issues in Educational Research, vol. 23 (2), 2013, pp. 132-150.

[13] Frank A.I., Mironowicz I.: Planning education in Poland [unpublished case study prepared for the Global Report on Human Settlements]. 2009, [on-line:]: http://unhabitat.org/wp-content/uploads/2010/07/GRHS2009CaseStudyChapter10Poland.pdf [access: 22 February 2015].

[14] Fraser D., Zentai L., Brandalize M.: The changing face of cartographic education and training. [in:] ICC2011 - the 25th International Cartographic Conference, International Cartographic Association, 2011, pp. 1-5. 
[15] Grzesik K., Źróbek S., Źróbek R.: Kierunki standaryzacji zasad wyceny nieruchomości w warunkach globalizacji. Studia i Materiały Towarzystwa Naukowego Nieruchomości, vol. 15 (1-2), 2007, pp. 9-22.

[16] Górecki R.J.: The University of Warmia and Mazury in Olsztyn as an Agent of Regional Development and Higher Education in Poland. Higher Education in Europe, vol. 26 (3), 2001, pp. 327-340.

[17] Janowski A., Jurkowska A., Przyborski M., Sobieraj A., Szulwic J., Wróblewska D., Wieczorek B.: Improving the quality of education through the implementation of the diplomas and group projects during engineering studies in cooperation with employers. [in:] 6th International Conference on Education and New Learning Technologies, Barcelona, Spain, 2014, pp. 978-984.

[18] Konecny G.: Recent global changes in geomatics education. International Archives of Photogrammetry Remote Sensing and Spatial Information Sciences, vol. 34 (6), 2002, pp. 9-14.

[19] Linn M.C., Davis E.A., Bell P.: Internet environments for science education. Routledge, 2013, [on-line:] https://www.google.pl/books?hl=pl\&lr=\&id=wERBomDOPqMC\&oi=fnd\&pg=PP1\&dq=educational+system+and+the+internet\&ots=cXSuXSST5L\&sig=sLPBs-T1CvH01aQzAY9pKrrtLS0\&redir_esc $=y \# v=$ onepage\&q=educational $\% 20$ system $\% 20$ and $\% 20$ the $\% 20$ internet\&f=false [access: 18 February 2015].

[20] Mikołajczyk Z.J.: Edukacja a równość szans w okresie transformacji. [in:] Kowalik T. (red.), Nierówni i równiejsi. Sprawiedliwość dystrybucyjna czasu transformacji w Polsce, Fundacja Innowacja, Warszawa 2002, pp. 312-346.

[21] Nikolli P., Idrizi B.: Geodetic and Cartographic Education in Albania. [in:] 3rd International Conference On Cartography and GIS, 15-20 June, 2010, Nessebar, Bulgaria, [on-line:] http://www.academia.edu/1863270/GEODETIC_AND_ CARTOGRAPHIC_EDUCATION_IN_ALBANIA [access: 6 June 2016].

[22] Pellegrino J.E., Cinami F.J., Pacheco S.P., Scroggins R.J., Miller C.L.: U.S. Patent No. 6,149,441. U.S. Patent and Trademark Office Washington 2000. [on-line:] https://www.google.com/patents/US6988138 [access: 18 February 2015].

[23] Polish Higher Education Act: Ustawa z dnia 18 marca 2011 r. o zmianie ustawy - Prawo o szkolnictwie wyższym, ustawy o stopniach naukowych $i$ tytule naukowym oraz o stopniach i tytule w zakresie sztuki oraz o zmianie niektórych innych ustaw. Dz.U. 2011, nr 84, poz. 455 [Journal of Laws 2011, no. 84, item 455].

[24] Salishchev K.A.: Geographic-cartographic education and the restructuring of higher education after the 27th Party Congress. Mapping Sciences and Remote Sensing, vol. 25 (1), 1988, pp. 10-18.

[25] Strategia rozwoju Wydziału Geodezji i Gospodarki Przestrzennej Uniwersytetu Warmińsko-Mazurskiego w Olsztynie na lata 2012-2020. Olsztyn 2012.

[26] Szyszka M.: Edukacja w Polsce - konieczność reformy i nowe wyzwania. Roczniki Nauk Społecznych, vol. 2 (38), 2010, pp. 255-274. 
[27] Vandell K.D.: Expanding the academic discipline of real estate valuation: A historical perspective with implications for the future. Journal of Property Investment and Finance, vol. 25 (5), 2007, pp. 427-443.

[28] Wegner S.B., Holloway K.C., Garton E.M.: The effects of Internet-based instruction on student learning. Journal of Asynchronous Learning Networks, vol. 3 (2), 1999, pp. 98-106.

[29] Źróbek S., Źróbek R.: Kierunki rozwoju systemu ksztatcenia specjalistów obstugi rynku nieruchomości. [in:] Marcinek K. (red.), Inwestycje i nieruchomości we wspótczesnej gospodarce: księga jubileuszowa prof. zw. dr hab. Haliny Henzel, Prace Naukowe Uniwersytetu Ekonomicznego w Katowicach, Wydawnictwo Uniwersytetu Ekonomicznego, Katowice 2013, pp. 201-212.

[30] Źróbek S., Grzesik C.: Modern challenges facing the valuation profession and allied university education in Poland. Real Estate Management and Valuation, vol. 21 (1), 2013, pp. 14-18. 